Bulletin UASVM Food Science and Technology 70(2)/2013, 141-142

ISSN-L 2344-2344; Print ISSN 2344-2344; Electronic ISSN 2344-5300

\title{
The Dynamic of Essential Oil Accumulation in Hop Cones during 2012 Year
}

\section{Liana-Claudia SALANȚĂ, Maria TOFANĂ, Sonia SOCACI, Elena MUDURA, Anca FĂRCAŞ}

Faculty of Food Science and Technology, University of Agricultural Sciences and Veterinary Medicine, 35 Mănăştur street, 400372 Cluj-Napoca, Romania, lili_sml@yahoo.com

\begin{abstract}
Hop cones have lupulin glands which occur on the outer lower surface of the bracteoles and the entire surface of the perianth. The constituents of these glands include bitter acids and essential oil components (Auerbach et.al., 2000). Dry hop contains 0.5-2.0\% of essential oil. Hop essential oils consist of a large number of different components and although their composition is influenced by the environment (Ĉerenak et.al., 2011). This study is a continuation of the research started in 2011 (Salanţă et.al., 2012), where the dynamic of essential oil accumulation in hop cones during 2011 year, were reported. In this paper, samples from 2012 year crop were subjected to hydrodistillation in order to content in essential oils. All reported results will be used in a future research, to determine the gas chromatographic composition of essential oils extracted.
\end{abstract}

Keywords: essential oil, hop cones, pellets, hydrodistillation

Introduction. The female inflorescence of hops is known as the hop cone or strobile. Hop cones have lupulin glands which occur on the outer lower surface of the bracteoles and the entire surface of the perianth. The constituents of these glands include bitter acids and essential oil components (Auerbach et.al., 2000). Dry hop contains 0.5-2.0\% of essential oil. Hop essential oils consist of a large number of different components and although their composition is influenced by the environment (Ĉerenak et.al., 2011).

Aims and objectives. This study is a continuation of the research started in 2011 (Salanţă et.al., 2012), where the dynamic of essential oil accumulation in hop cones during 2011 year, were reported. In this paper, samples from 2012 year crop were subjected to hydrodistillation in order to content in essential oils. All reported results will be collected and used in a future reserch to determine the gas chromatographic composition of essential oils extracted and to distinguish the most relevant compounds in order to use them as markers in the authentication of plant variety.

Materials and method. The study of volatile oil dynamic accumulation in cones was carried out for three varieties of hop: Magnum (MG), Hüller Bitterer (HB) and Aroma (AR), in different phenophases: during the formation, ripening and harvesting. The samples of hop cones were collected from Seleuş farms from Mureş, a traditional Romanian hop grower,during 2012 year. The pellets samples were received from the farm, but the grower do not process Aroma cones into pellets, because this hop cultivar is grown on a small area and the cones are combined with the ones from other aromatic varieties. The samples were codified as follows: Ceo (essential oil from dried cones), Feo (essential oil from hop flower), Peo (essential oil from pellets). Samples of hop essential oil were isolated by hydrodistillation, method described by Salanta et.al., 2012. Relative accumulation is calculated from the total oil determined in cones, and it shows the percentage differences of oil accumulation during phenophases. Relative increase 
shows the percentage growth between phenophases and is calculated by the difference between phenophase 2 and 1, respectively phenophase 3 and 2 .

Results and discussions. The obtained results are presented in Tab. 1.Volatile oil relative accumulation in hop cones during phenophases is progressive in all three varieties of hops, achieving a maximum in phenophase III. The character of hop variety influence the accumulation in volatile oil, as it can be seen the Aroma variety accumulation in volatile oil is higher than the other two varieties. The volume of essential oils collected from hop flower is higher, in most of the samples, than the volumes extracted from dried cones, because a part of volatile oils is lost during drying. The volume of volatile oil from pellets is lower than the volume extracted from cones samples due to the pelleting process, the same was reported by Salanta et al., 2012. Comparing the results obtained from the harvest year 2011 with those obtained in 2012, it can be seen a decrease in essential oil accumulation due the weather conditions in the growing season.

The accumulation of volatile oil in hop cones and pellets

\begin{tabular}{|c|c|c|c|c|c|c|c|}
\hline $\begin{array}{c}\text { Crt. } \\
\text { no }\end{array}$ & Phenophases & $\begin{array}{c}\text { Date } \\
\text { harvest }\end{array}$ & $\begin{array}{l}\text { Sample } \\
\text { weight } \\
\text { (g) }\end{array}$ & $\begin{array}{l}\text { Sample } \\
\text { cod }\end{array}$ & $\begin{array}{l}\mathrm{ml} / 100 \mathrm{~g} \text { dry } \\
\text { matter }\end{array}$ & $\begin{array}{c}\text { Relative } \\
\text { accumulation } \\
\text { [\% of total] }\end{array}$ & $\begin{array}{c}\text { Relative } \\
\text { increase } \\
{[\%]}\end{array}$ \\
\hline 1. & \multirow[t]{2}{*}{ FN I } & \multirow[t]{2}{*}{21.08 .2012} & 50.1143 & AR-Ceo & 1.04 & 37.96 & - \\
\hline 2. & & & 51.0548 & AR-Feo & 0.82 & 28.17 & - \\
\hline 3. & \multirow[t]{2}{*}{ FN II } & \multirow[t]{2}{*}{4.09 .2012} & 50.6046 & AR-Ceo & 1.44 & 52.55 & 14.59 \\
\hline 4. & & & 51.5421 & AR-Feo & 2.16 & 74.23 & 46.06 \\
\hline 5. & \multirow[t]{2}{*}{ FN III } & \multirow[t]{2}{*}{18.09 .2012} & 50.9026 & AR-Ceo & 2.74 & 100 & 47.45 \\
\hline 6. & & & 50.1819 & AR-Feo & 2.91 & 100 & 25.77 \\
\hline 7. & \multirow[t]{2}{*}{ FN I } & \multirow[t]{2}{*}{21.08 .2012} & 50,0012 & $\mathrm{HB}-\mathrm{CeO}$ & 0,67 & 26.38 & - \\
\hline 8. & & & 52.4517 & HB-Feo & 0.90 & 31.91 & - \\
\hline 9. & \multirow[t]{2}{*}{ FN II } & \multirow[t]{2}{*}{4.09 .2012} & 50.5032 & HB-Ceo & 1.27 & 50.00 & 23.62 \\
\hline 10. & & & 59,2039 & HB-Feo & 1.19 & 42.19 & 10.28 \\
\hline 11. & \multirow[t]{2}{*}{ FN III } & \multirow[t]{2}{*}{18.09 .2012} & 50.0912 & HB-Ceo & 2.54 & 100 & 50.00 \\
\hline 12. & & & 51.2038 & HB-Feo & 2.82 & 100 & 57.81 \\
\hline 13. & PELETI & 08.01 .2013 & 51.0531 & HB-Peo & 1.35 & - & - \\
\hline 14. & \multirow[t]{2}{*}{ FN I } & \multirow[t]{2}{*}{21.08 .2012} & 43.4701 & MG-Ceo & 0.39 & 13.59 & - \\
\hline 15. & & & 52.3047 & MG-Feo & 0.65 & 25.19 & - \\
\hline 16. & \multirow[t]{2}{*}{ FN II } & \multirow[t]{2}{*}{4.09 .2012} & 50.1023 & MG-Ceo & 1.27 & 44.25 & 30.66 \\
\hline 17. & & & 57.1037 & MG-Feo & 1.06 & 41.06 & 15.87 \\
\hline 18. & \multirow[t]{2}{*}{ FN III } & \multirow[t]{2}{*}{18.09 .2012} & 50.1945 & MG-Ceo & 2.87 & 100 & 55.75 \\
\hline 19. & & & 49.7328 & MG-Feo & 2.58 & 100 & 58.94 \\
\hline 20. & PELETI & 08.01 .2013 & 51.1845 & MG-Peo & 1,71 & - & - \\
\hline
\end{tabular}

Conclusion. The volume extracted is depending on the phenophase of the cones, the drying process and the industrial processing of cones in pellets, the results can be useful in the optimal harvesting period.

\section{REFERENCES}

1.Auerbach, Rita H., Dost, K., Davidson, G., (2000). Characterization of Varietal Differences in Essential Oil Components of Hops (Humulus lupulus) by SFC-FTIR Spectroscopy, Journal of AOAC international vol. 83, NO. 3.

2.Ĉerenak, Andreja, Pavloviĉ, M., Monika Oset Luskar, Košir, I.J., (2011). Characterisation of slovenian hop (Humulus Lupulus L.) varieties by analysis of essential oil, Hmeljarski bilten / Hop Bulletin 18 , p.27-32.

3.Salanţă, Liana-Claudia, Maria Tofană, Sonia Socaci, Elena Mudura, (2012). The Dynamic Of Essential Oil Accumulation In Hop Cones During 2011 Year, Bulletin Of University Of Agricultural Sciences And Veterinary Medicine Cluj-Napoca Agriculture, 69(2), p.521-523. 